\title{
ASSESSING READINESS LEVELS OF PRODUCTION TECHNOLOGIES FOR SUSTAINABLE INTENSIFICATION OF AGRICULTURE
}

\author{
Mariusz Maciejczak ${ }^{1}$, Janis Faltmann ${ }^{2}$ \\ ${ }^{1}$ Warsaw University of Life Sciences - SGGW, Nowoursynowska 166, 02-787 Warsaw, Poland, \\ e-mail: mariusz_maciejczak@sggw.pl \\ ${ }^{2}$ University of Hohenheim, Schloss Hohenheim 1, 70599 Stuttgart, Germany, \\ e-mail: janis.faltmann@uni-hohenheim.de
}

\begin{abstract}
The modern agricultural production is facing the problem of a growing society connected with the growing asking for food as well as different environmental threats. To solve this issue, agricultural production should be more sustainable and efficient which can be reached by using new technologies. In the paper the most important technologies, which were evaluated by different research methods to find how and when they could be used for a sustainable intensification of agriculture were highlighted by applying technology and market readiness models. By asking professionals from different fields of agriculture in practice as well as academia it was found that technologies that collect or utilize advanced data (sensors, drones) used for knowledge based management are more applicable for use, contrary to nanotechnologies where the costs of development and applications limits the readiness.
\end{abstract}

Keywords: Sustainability, Technology Readiness, Market Readiness, Poland, Germany

(JEL Classification: Q16)

\section{Introduction}

Agriculture is a major area of human activity affecting both its safety and well-being and the environment in which it lives. It thus becomes the primary factor conditioning global changes. Agriculture should be treated as a complex system with inherent adaptive abilities (Maciejczak, 2017). The complexity of agriculture is the result of the interplay of its individual elements as well as the interconnections of elements throughout the system and between the system and its surroundings. Over the centuries the economic pressures have led to systemic domination of agriculture based on the mechanisms of commercialization, concentration, specialization, agrarian structural change and capital-intensive intensification. Such actions have led to the imbalance in both the natural and the social systems interacting with agriculture. Currently, agriculture is facing many problems, i.e. the need for the increase of food production by $60-110 \%$ by 2050 due to the population growth while ensuring at the same time the protection of the environment under the sustainability demand (Foley at al., 2005). In order to face these issues, the dominating concept of quantitative (solely economic) growth is being replaced by the approach of the development based on the qualitative - more sustainable nature. Tittonell postulates adaptation actions within the complex agricultural system, based on strategies for further intensification, however based on the sustainable assumptions (Tittonell, 2014). This could be induced in a number of different ways with only the two most effective ones being pointed out here. The first is called industrial intensification and aims to maintain the industrial path based on innovation in the technological and organizational sphere. The second named as agro-ecological intensification is focusing on the intensification of more targeted agro-ecosystems, the use of more production-friendly technologies that provide better harmonization of production and environmental objectives. The future prospect of modern industrialized agricultural systems is being challenged on several fronts because of its dependence on capital, external energy and agrochemical inputs, and for its adverse impact on biodiversity and on human health (Struik et al., 2014).

Regardless of the strategic options of sustainable intensification, this concept requires application of innovative technologies. Today agriculture is demanding technological solutions with the aim of increasing production or accurate inventories for sustainability while the environmental impact is minimized by reducing the application of agro-chemicals and increasing the use of environmental friendly agronomical practices. The technologies of modern agriculture are however in different stages of development and use. This significantly influences the dynamics of changes in agriculture. Therefore, 
the main objectives of the paper are threefold. Firstly, the paper aims to present, based on literature review, the needs and solutions for innovative technologies which are most promising for further development of modern model of sustainably intensive agriculture. However, due to the paper's limitations the discussion about the issues of the sustainability of the technologies will not be made. It is assumed that the selected technologies are sustainable based on the researches of other authors. Secondly, using the foresight approach, it aims to assess the technology and market readiness levels of selected technologies. Finally, based on experts' opinion, it will provide the recommendations for development and diffusion of the most perspective technologies. It is assumed that the more information for knowledge based management is collected by the technology the better its diffusion and use.

\section{MATERIAL AND METHOD}

This paper uses different methodologies selected to correspond best to the goals set. The investigations are based on primary and secondary data sources. Firstly, the literature review of scientific papers was performed. Using different key words, based on abstract review, there were selected 79 papers, which later, after full text analysis, were reduced to 17 . Based on the review 10 most promising technologies were selected, 6 from crop production and 4 from animal production. The primary data comes from the Real-Time Delphi survey. The rationale for the choice of the foresight heuristic Delphi method was more the hypothetical then empirical impact of selected technologies for modern agriculture. There was used Real-Time Delphi approach (GRISHAM, 2009). Using a web-based tool a qualitative and quantitative survey was held. The questionnaire was open from 1st May 2017 to 31st August 2017. There were identified 10 experts from two countries: Poland and Germany. From each country participated 5 experts being: farmers, technology developers and traders, consumers, policy makers and academics. All experts were chosen deliberately because of their knowledge about agriculture and its technological advancement. However, due to the relatively limited number of the experts, their opinions and through results of the foresight study should be considered with appropriate reservation. There was a basic assumption about possible application and impact of assessed technology in mid-term perspective of 2025 having in mind the needs of sustainable development. Two scales of Technology Readiness Level (TRL) and Market Readiness Level (MRL) were applied. TRL enables the assessment of the maturity of a particular technology and the consistent comparison of maturity between different types of technologies. It is based on a scale from 1 to 9 , with 9 being the most mature technology (EARTO, 2011). MRL enables the assessment of the readiness of technology for commercialisation and diffusion. It is based on a scale from 1 to 5 , with 5 being the most marketable (AASRUD et al., 2010). To analyse linkages between TRL and MRL the rho-Spearman correlation test was used (PARLIŃSKA and PARLIŃSKI, 2011).

\section{RESULTS AND DISCUSSION}

Modernisation in agriculture is a very relative concept (ILO, 1991). It differs very much depending on the country, the region as well as on individual farm perspective. Many factors are associated with the progress made due to implementation of new techniques, technology or other innovative solutions. Therefore, for the purpose of this research, the framework for the concept of the modernization of agriculture will be established. The analysis is limited to the European perspective with the focus on developed farms which are considered as enterprises. For such farms, implementation of innovations, esp. in forms of new technologies is attached to the umbrella approach of precision agriculture. It is a farming management concept based on observing, measuring and responding to inter and intra-field variability in crops, or to aspects of animal rearing (TAKACS-GYORGY et al., 2014). The benefits to be obtained are chiefly due to increased yields and/or increased profitability of production to the farmer. Other benefits are better working conditions, increased animal welfare and the potential to improve various aspects of environmental stewardship. As stressed by (WEISS, 1996) the implementation of precision farming has become possible as a result of the development of innovative technologies i.e. sensors, or drones combined with procedures to link mapped variables to appropriate farming practices such as tillage, seeding, fertilization, herbicide and pesticide application, harvesting and animal husbandry. Subsequently, it is relying on automatic monitoring of individual animals and is used to monitor animal behaviour, welfare and productivity as well as their physical environment. Advances in nanotechnologies could also be implemented in a wide spectrum i.e. for health maintenance of both animals and plants. Nevertheless, one needs to remember that the adoption of this concept encounters specific challenges not only due to the size and diversity of farm structures but also due to the readiness of available technologies to meet high demands of technological, economic, social and environmental efficiency. The detailed literature review enabled us to distinguish 10 technologies that could contribute the most to the development of precision agriculture (table 1).

The Delphi results of the technological and market readiness levels of selected technologies (fig. 1 and fig. 2) showed for both perspectives similar results. Also, the calculated rho-Spearman correlation between TRL and MRL confirmed a strong correlation on the level of 0.933 ( $\mathrm{r}<$ 0.001 ). It means that the market readiness is closely associated with the technological readiness. The more technology is prepared to be implemented on the market the more market is creating conditions for its release.

With this respect, the majority of experts agreed also on the importance of knowledge, which could be considered as a fourth dimension of market readiness (BOS et al., 2013). The farmers need to know how the technology works and what the benefits of its use are, not on experimental fields, but in other farms. 
Table 1. Top 10 technologies of future sustainable agriculture - a literature review

\begin{tabular}{|c|c|c|}
\hline Technology & Description & Authors \\
\hline \multicolumn{3}{|l|}{ Crop production } \\
\hline Nanotechnology & Use nanotechnology for disease control in crop production. & $\begin{array}{l}\text { Fraceto et al., 2016, } \\
\text { Kuzma \& VerHage, } 2006\end{array}$ \\
\hline Yield & $\begin{array}{l}\text { Use all the data that is collected from guidance system to get an over- } \\
\text { view over your work and in- and output. }\end{array}$ & $\begin{array}{l}\text { Takacs-Gyorgy et al., 2013, Fran- } \\
\text { cik, } 2010\end{array}$ \\
\hline Soil mapping & $\begin{array}{l}\text { Use tractor mounted sensors to get information about the nitrogen in } \\
\text { the soil to control the fertilizer use. }\end{array}$ & $\begin{array}{l}\text { Frewer et al. 2011, } \\
\text { Sanders and Masri, } 2016\end{array}$ \\
\hline Drones & $\begin{array}{l}\text { Use drones to analyse e.g. the chlorophyll content of the crops to use } \\
\text { fertilizer or pesticides more precisely. }\end{array}$ & $\begin{array}{l}\text { Gozdowski et al., 2010, } \\
\text { Dukaczewski and Bielecka, } 2009\end{array}$ \\
\hline Sensors & $\begin{array}{l}\text { Get more sensors connected through new and cheaper systems than } \\
\text { SIM Cards. }\end{array}$ & $\begin{array}{l}\text { Jensen et al., 2012, } \\
\text { Ojha et al. } 2015\end{array}$ \\
\hline Autonomy & $\begin{array}{l}\text { Use fully autonomous tractors to reduce labour costs and work more } \\
\text { efficiently. }\end{array}$ & $\begin{array}{l}\text { Dukaczewski and Bielecka, 2009; } \\
\text { Xiweia and Xiangdong, } 2007\end{array}$ \\
\hline \multicolumn{3}{|l|}{ Animal production } \\
\hline Devices & $\begin{array}{l}\text { Use smart devices like electronic earmarks to get information about the } \\
\text { position and health of animals. }\end{array}$ & $\begin{array}{l}\text { English et al., } 2013 \text {, } \\
\text { Cupiał et al., } 2015\end{array}$ \\
\hline Data & $\begin{array}{l}\text { Use on-time software to get recent information about e.g. the feeding } \\
\text { behaviour of your animals. }\end{array}$ & $\begin{array}{l}\text { Tyler and Griffin, 2016, } \\
\text { Cupiał et al., } 2015\end{array}$ \\
\hline Nanotechnology & $\begin{array}{l}\text { Use nanotechnology to make a more precise diagnoses as well as creat- } \\
\text { ing smart medicine. }\end{array}$ & $\begin{array}{l}\text { Parisi et al., 2014, } \\
\text { Głód et al., } 2014\end{array}$ \\
\hline Sensors & $\begin{array}{l}\text { Use more sensors to monitor and control different variables of the } \\
\text { digestion and wellbeing of the animals. }\end{array}$ & Kopiński ,2014, Ojha et al., 2015 \\
\hline
\end{tabular}

Source: own research results, 2017

Fig. 1. Technology Readiness Level of analysed technologies.

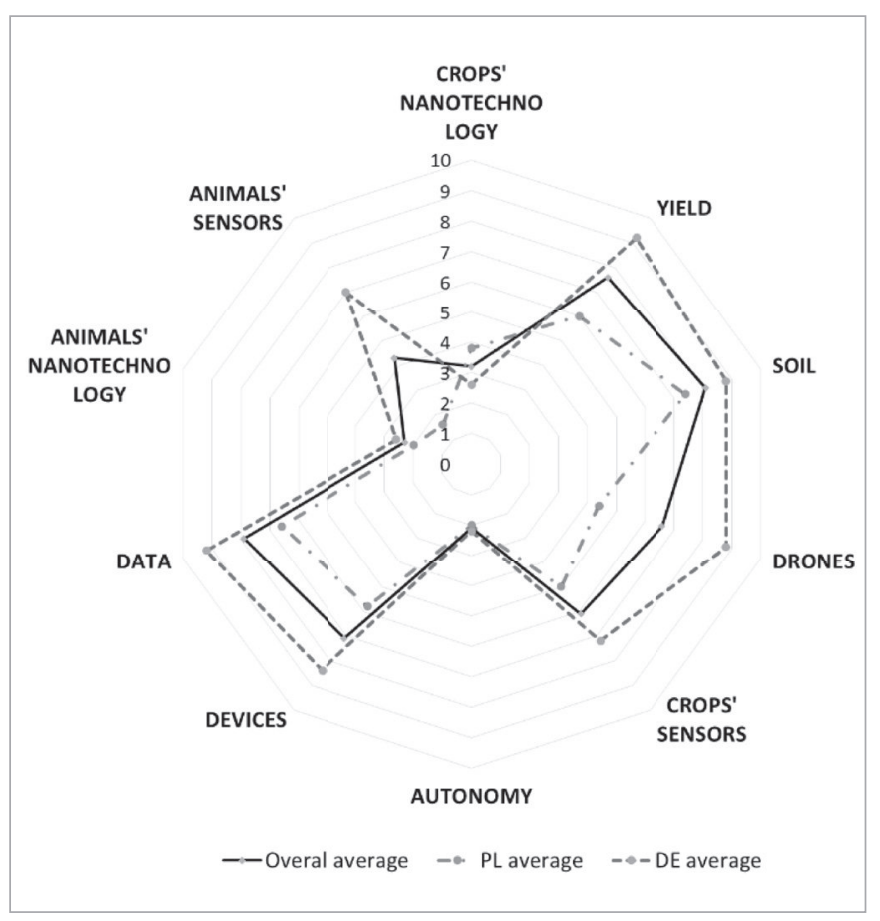

Source: own investigationreview
Fig. 2. Market Readiness Level of analysed technologies.

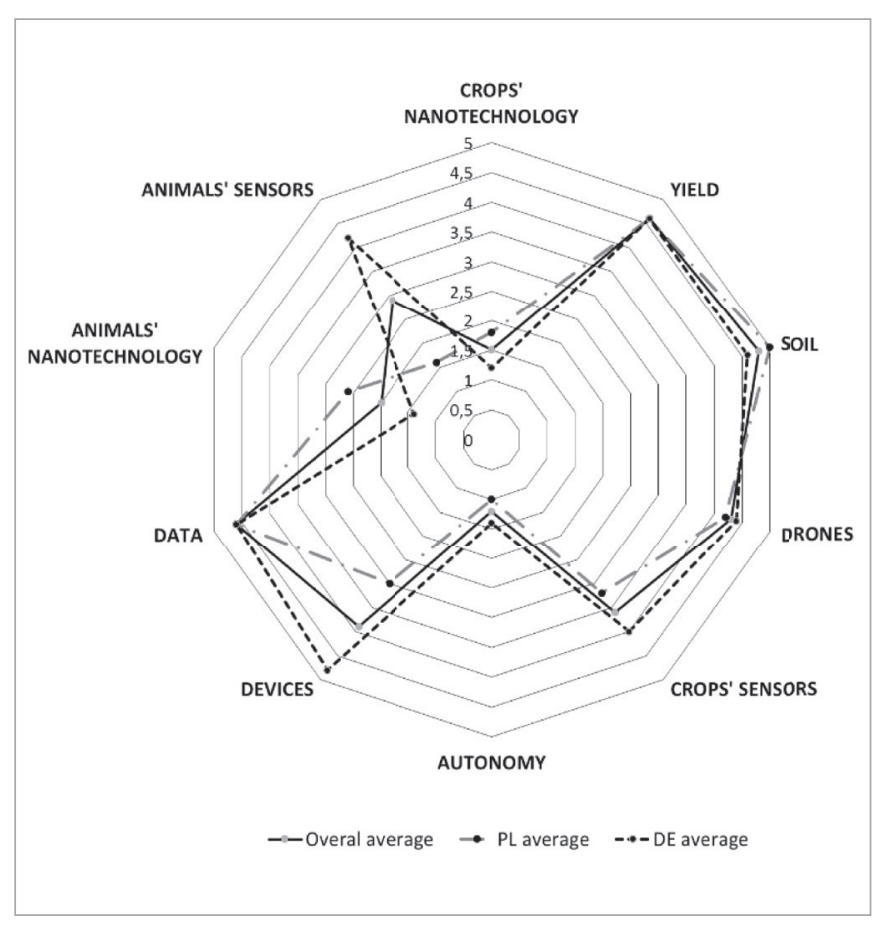

Source: own investigationreview 
The analysis and evaluation of the different opinions of the experts showed that there are many similarities as well as differences in the way Polish and German experts are seeing the market and technology readiness of the chosen technologies. The average value for nanotechnology in crop production in terms of technology readiness was 3.2. This is a quite low value. The German experts saw an average TRL at 2.6 and the Polish experts at 3.8. The market readiness was on average also very low (1.5). With 1.8 the Polish experts were more optimistic with this technology while the German experts saw it at a low value of 1.2. The most common opinion was that nanotechnology in crop production is an interesting technology but application will need more time and a high investment. Some experts were not optimistic at all but this is often the case when talking about technologies of the far future. Nanotechnology in animal production seems to be again a technology that will be more interesting in far future. Thus, it gets low values of TRL (overall average 2.3, Germany 2.6 and Poland 2) and MRL (overall 2, Poland 2.6 and Germany 1.4). It is interesting that those values are lower than the values for Nanotechnology in crop production. The argumentation was in part the same, but it seems that the experts are more comfortable to use this technology with crops than with animals. Despite the numerous potential advantages of nanotechnology and the growing trends in publications and patents, agricultural applications have not yet made it to the market (Parisi et al., 2015). Several factors could explain the scarcity of commercial applications, i.e. agricultural nanotechnology does not demonstrate a sufficient economic return to counterbalance the high initial production investments (Chena and Yadab, 2011).

Collecting data from your guidance system is far readier in terms of technology and market readiness. With an overall average TRL of 7.6 and 9.2 in Germany and 6 in Poland and an average MRL of 4.6 in general, in Poland and Germany the technology is already adopted in those countries. From German experts, there were concerns about the user-friendliness of the product. In Poland, this technology is just used by big farms which means that there is some space for development. Beside data collection, soil analysis was also a technology that was ranked highly in terms of readiness levels. The average values for TRL were 8.1 overall, 7,4 for Poland and 8.8 for Germany. The values for MRL were 4.8 in general, 5 in Poland and 4.6 in Germany. This technology is also already adopted to the market and needs some improvements in terms of costs so that also small farmers can use it. As informed by some authors data collecting and analysis will form new dimension for decision making in agriculture (WANG et al., 2006). The big farms already benefit from the bid data approach and through contribute for sustainable intensification. Now the gravity point is moving towards smaller farms whom needs to see the direct benefits for the cost-effectiveness of their operations and risk reduction as well as for external benefits for the environment and society, i.e. reducing carbon emission.

Drones had average values more in the middle field (6.6). What was interesting is that the TRL for Germany (8.8) and Poland (4.4) were quite different. The same occurred for the
MRL where the average for all was 4.1, for Poland 3.8 and for Germany 4.4. The German experts were still not happy about the costs. Furthermore, experts argued that the technology is not useful due to the fact that modern satellite pictures could bring the same information. The Polish experts were really sure that this technology will help to become more sustainable. Mazur showed that drone technology will give the agriculture industry a high-technology makeover, with planning and strategy based on real-time data gathering and processing (MAZUR, 2016). PwC estimates the market for drone-powered solutions in agriculture at over 30 billion USD. The show that thanks to robust investments and a somewhat more relaxed regulatory environment, it appears their time has arrived, especially in agriculture (PwC, 2016).

Sensors left also some room between both experts. In general, the TRL was 6,1 while the value in Germany was 7.2 and in Poland 5. The market readiness was in average 3.5 and in Poland 3 and Germany 4. The opinion of the Polish experts was really positive on that technology. The opinions of the German experts were also positive. One expert said that the technology will only be important if a farmer uses a completely automatic system. For sensors in animal production the average value for TRL was 4,3 while Germany was really high with 7 and Poland really low with 1.6. The MRL was in average 2.8 while in Poland 1.4 and in Germany 4.2. The Polish experts are seeing many problems in the difficulty of measuring the values. German experts were more optimistic, due to the fact that sensors are getting cheaper. One key of this technology is that the data should be made usable. One can agreed that sensorsbased technologies provide appropriate tools to achieve the sustainability goals (Pajares et al. 2013). The explosive technological advances and development removed many barriers for their implementation, including the reservations expressed by the farmers themselves. Precision Agriculture is an emerging area where sensor-based technologies play an important role.

With autonomy in crop production, that last technology was a big topic of the future. The TRL in general was 2.1 in Germany 2.2 and in Poland 2. The MRL was low as well. In average, it was 1.4 in Germany 1 and in Poland 1. The biggest problem from German experts were the legal issues while the Polish experts argued more that autonomy will just be a topic of some niches. In animal production, the devices got an average TRL of 7.1. The value for Poland was 5.8 and the value for Germany 8.4. The MRL was 3.9 in average, 3 in Poland and 4.8 in Germany. Here you can see again big differences. The Polish and German concerns are that this technology is too expensive to be adopted. For data analyses in animal production the values of TRL are also different. In average, it is 7.9 while for Poland it is 6,6 and for Germany 9.2. The MRL is in both cases 4.6. In Germany, the technology should be better developed in terms of usability. The Polish doubts are connected with the farmers' knowledge for using this technology. The autonomous tractors were among the first autonomous vehicles by land, water or air but only now are they starting to be sold in 
volume (HARROP et al., 2017) showed. Current driverless tractor technologies build on recent developments in hybrid powertrains - more controllable and environmental - other autonomous vehicles and new agricultural technology. The idea of a versatile, programmable driverless tractor emerged in 2011 and 2012 out of "follow me" technology. It indicates that the capability to execute autonomous actions or doing this remotely enabling better decision making and actuation, not only at the production stages, but also throughout the whole value chain.

\section{CONCLUSIONS}

The conducted research confirmed that development of modern model of agriculture requires strategic options based on sustainability approach applied similarly and comprehensively on the intensification concept. This could be obtained and driven by the application of modern technologies. These technologies have a great potential to provide benefits of sustainable values. It was proved, however that the technologies that could bring these values are on different technological readiness and thus its market readiness is also different. The highest TRL and MRL results showed technologies that collect (i.e. sensors or drones) or use (soil or yield management systems) of data. The lowest results were obtained with very advanced technologies connected to nanomaterials. This suggest that for sustainable management of modern agriculture the more detailed data are needed and the more technology is fulfilling this requirement for knowledge building the bigger its readiness and diffusion. On other hand nanotechnologies, which development is very expensive are very promising, but in mid-term perspective they application due to the costs and efficiency is limited.

It needs to be pointed out that the technological development of agriculture, based on a number of technologies coming concurrently from outside the agricultural sector, such as global positioning systems, cloud computing, drones and the Internet of Things (IoT), under the sustainability framework, raises also significant legal and socio-ethical questions. These concern the terms of safeguarding sustainable agri-food production, the conditions under which farmer - related data are collected and processed and the role of the individual farmer. This requires further research as more technologies will be ready for commercial use in close future, that will make the significant difference for the future.

\section{ACKNOWLEDGEMENTS}

The draft version of this research was presented at the IX International Scientific Symposium "Farm Machinery and Processes Management in Sustainable Agriculture" held on 22-24 November 2017 in Lublin, Poland. The authors acknowledge all comments and remarks from conference's participants that contributed to the development of this paper. Also the remarks from the anonymous reviewers of the final version are kindly appreciated.

\section{REFERENCES}

Aasrud A., Baron R. and Karousakis K. (2010). Market readiness: building blocks for market approaches. Organisation for Economic Co-operation and Development, 7-21

Cupiał M., Szeląg-Sikora A., Niemiec M. (2015). Optimisation of the machinery park with the use of OTR-7 software in context of sustainable agriculture. Agriculture and Agricultural Science Procedia 7(2015), 64 - 69

Bos J., Smit A., Schröder J. (2013). Is agricultural intensification in The Netherlands running up to its limits? NJAS - Wageningen Journal of Life Sciences, Volume 66, November 2013, Pages 65-73

Chena H., Yadab T. (2011). Nanotechnologies in agriculture: New tools for sustainable development. Trends in Food Science \& Technology, Volume 22, Issue 11, November 2011, 585-594

Dukaczewski D., Bielecka E. (2009). Nowe teledetekcyjne misje satelitarne i możliwości wykorzystania ich wyników do zasilania baz danych przestrzennych. Roczniki Geomatyki, T. VII, Z. 5(35), 41-54.

EARTO - European Association of Research and Technology Organisations (2014). The TRL Scale as a Research \& Innovation Policy Tool, EARTO Recommendations. Brussels.

English A., Ball D., Ross P., Upcroft B., Wyeth G., Corke P. (2013). Low Cost Localisation for Agricultural Robotics. Proceedings of Australasian Conference on Robotics and Automation, 2-4 Dec 2013, University of New South Wales, Sydney Australia.

Foley, J.A., R. DeFries, G.P. Asner, C. Barford, G. Bonan, S.R., Carpenter, F.S. Chapin, M.T. Coe, et al. (2005). Global consequences of land use. Science 309, 570-574.

Fraceto L., Grillo R., Medeiros G.A., Scognamiglio V., Bartolucci C. (2016). Nanotechnology in Agriculture: Which Innovation Potential Does It Have? Front. Environ. Sci. 4: 20, 1-5

Francik, S. (2010). Analiza wykorzystania przez rolników programów komputerowych do wspomagania decyzji. Inżynieria Rolnicza, 7(125), 47-54.

Frewer L.J., Bergmann K., Brennan M., Lion R., Meertens R., Rowe G. et al. (2011). Consumer response to novel agri-food technologies: implications for predicting consumer acceptance of emerging food technologies. Trends in Food Science \& Technology 2011, 22(8), 442-456.

Głód D., Adamczak M., Bednarski W. (2014). Wybrane aspekty zastosowania nanotechnologii w produkcji żywności. Żywność. Nauka. Technologia. Jakość, nr 5(96), 36-52.

Gozdowski D., Samborski S., Bobers E S. (2010). Evaluation of methods for detection of spacial outliners in the yield data of winter wheat. Colloquium Biometricum 40, 41-51.

Grisham T. (2009). The Delphi technique: a method for testing complex and multifaceted topics. International Journal of Managing Projects in Business Vol. 2 No. 1, 112-130

Harrop P., Ghaffarzadeh K., Harrop J., Zervos H., Gonzalez F. (2017). Autonomous Vehicles Land, Water, Air 2017-2037. Research and Markets, Dublin

ILO, International Labour Office (1991). The Application of Modern Agricultural Technology: Sixth Item on the Agenda. Report of International Labour Conference, 78th Session, 1991, Geneva

Jensen H.G., Jacobsen L., Pedersen S. M., Tavella E. (2012). Socioeconomic impact of widespread adoption of precision farming in Denmark. Precision Agricutlure, 13, 661-667.

Kopiński J. (2014). Trendy zmian głównych kierunków produkcji zwierzęcej w Polsce w okresie członkostwa w UE. Prace nau- 
kowe UE we Wrocławiu, 361/2014, 117-129.

Kuzma, J., VerHage, P. (2006). Nanotechnology in Agriculture and Food Production: Anticipated Applications. Project on Emerging Nanotechnologies. Wilson International Center for Scholars, Washington, DC.

Maciejczak M. (2017). Bioeconomy as a Complex Adaptive System of Sustainable Development. Journal of International Business Research and Marketing, Volume 2, Issue 2, 2017, 7-10

Mazur M. (2016). Six Ways Drones Are Revolutionizing Agriculture. MIT Technology Review, July 2016, 16-18

Ojha T., Misra S., Raghuwanshi N.S. (2015). Wireless sensor networks for agriculture: The state-of-the-art in practice and future challenges. Computers and Electronics in Agriculture, 118 (2015), 66-84.

Pajares G., Peruzzi A., Gonzalez-de-Santos P. (2013). Sensors in Agriculture and Forestry. Sensors (Basel). 2013 Sep; 13(9): 12132-12139.

Parisi C., Vigani M. and Rodríguez-Cerezo E. (2014). Proceedings of a workshop on "Nanotechnology for the agricultural sector: from research to the field". The Institute for Prospective Technological Studies (IPTS) of the European Commission's Joint Research Centre (JRC), Seville, Spain, 42-56.

Parisi C., Vigani M. and Rodríguez-Cerezo E. (2015). Agricultural Nanotechnologies: What are the current possibilities? Nano Today, Volume 10, Issue 2, April 2015, 124-127

Parlińska M., Parliński J., (2011). Statystyczna analiza danych z Excelem. Wyd. SGGW, Warszawa

PwC (2016). Global report on the commercial applications of drone technology. PriceWaterhouseCoopers (PwC), Warsaw, Poland

Sanders K.T., Masri S.F. (2016). The energy-water agriculture nexus: the past, present and future of holistic resource management via remote sensing technologies. J. Cl. Prod. 117 (2016), 73-88.

Struik, P.C., Kuyper T.W., Brussaard L. and Leeuwis C. (2014). Deconstructing and unpacking scientific controversies in intensification and sustainability: Why the tensions in concepts and values? Current Opinion in Environmental Sustainability 8, 80-88.

Takacs-Gyorgy K., Lencsés E., Takacs I. (2013). Economic benefits of precision weed control and why its uptake is so slow. Studies in Agricultural Economics 2013: (1), 40-46.

Takacs-Gyorgy K., Rahoveanu T., Magdalena M., Takacs I. (2014). Sustainable New Agricultural Technology - Economic Aspects of Precision Crop Protection. Procedia Economics and Finance, Volume 8, 2014, 729-736

Tittonell P. (2014). Ecological intensification of agriculture sustainable by nature. Current Opinion in Environmental Sustainability, 8/2014, 53-61.

Tyler B. M., Griffin T. (2016). Defining the Barriers to Telematics for Precision Agriculture: Connectivity Supply and Demand. Southern Agricultural Economics Association's 2016 Annual Meeting, San Antonio, Texas, February, $6 \square 92016$.

Wanga N., Zhang M., Wang M. (2006). Wireless sensors in agriculture and food industry-Recent development and future perspective. Computers and Electronics in Agriculture, Volume 50, Issue 1, January 2006, 1-14

Weiss, M.D. (1996): Precision farming and spatial economic analysis: Research challenges and opportunities. American Journal of Agricultural Economics. 78(5), 1275-1280.

Xiweia Z. and Xiangdong Y., (2007). Science and technology policy reform and its impact on China's national innovation system. Technology in Society, Volume 29, Issue 3, August 2007, 317-325 


\title{
THE ROLE OF „HANDBALL AT SCHOOL” PROGRAM IN ABILITY DEVELOPMENT AND REPLENISHMENT TRAINING
}

\author{
Anetta Müller, István Juhász, Eszter Boda, Melinda Biró, Zsuzsa Nagy
}

University of Debrecen Faculty of Economics, e-mail: bacsne.baba.eva@econ.unideb.hu

\begin{abstract}
In Hungary the undisputable merit of TAO subsidy is realized in replenishment training, human resource development and development of sports infrastructure. The other important base of replenishment development is „Handball at School” programme managed by Hungarian Handball Federation. „Handball at School” programme was launched in relation to every-day physical education and we undertook the skills-building role of its impact assessment. A survey programme was organised by us in the autumn and spring semesters of 2015/ 2016 academic year aiming to prove that project has positive effect on aiming accuracy and performance stability results of pupils, as well as their precision of technical implemetation. 183 pupils were examined who had two sponge-handball lessons a week out of their 5 physical education lessons. When choosing the pilot scenes it was considered important to get Budapest, Easternand Western Hungary also involved. To examine aiming accuracy two tests were applied. One is „throwing at a target from throwing straddle without previous swing" performed by the pupils. The children were expected to hit the small box five times with right technical implementation meaning that it was done with lifted elbow. After the first implementation they were given some time to relax and the the shots were repeated five times again. The children were asked another task to perform, a similar one to the first, but it had to be performed from running up, that is they ran back from a line, took the sponge ball, ran back to the line and had to hit the small box again with lifted elbow. At this task several aspects were noted and measured again: the time needed for implementation, target accuracy and also whether the technical implementation of the throw was accurate.
\end{abstract}

Keywords: : Handball, TAO, Every-Day Physical Education, Aiming Accuracy, Speed Coordination

(JEL Classification: I21, Z28)

\section{Introduction}

TAO subsidy system for visual team sports was introduced in Hungary in 2011. The objective of the modification of Act LXXXI of 1996 on Corporate Tax and Dividend Tax (abbrev. TAO) was legal regulation of the sports-friendly tax (András, 2014). The act was accepted by EU, which became unprecedental, thanks to its regulations concerning sports. On 1. July 2011. Act LXXXII. of 2011on the Modification of Certain Acts on Sports Subsidy and its Implementing Regulations came into effect (Bardóczy 2014).

The objective of the Act is to ensure direct state subsidy for visual team sports (football, handball, basketball, ice hockey, and water polo).

The beneficiaries can spend the resources comingfrom TAO on tangible investment, renovation, personal expences and educational costs. In 2011tax year 2618 tax payers benefited 20,4 bn HUF tax advantage on sports purposes, until 2012. 21 December it was already 25 billion (Bardóczy 2014).

An undisputable merit of TAO is that it has outstanding role both in replenishment training and in professionals' training as well (Dajnoki et al. 2015). Although in Debrecen football is outstanding from TAO aspect, in handball sport they applied in 2011-2014 for 660108000 HUF for replenishment training from which 509129000 HUF was won on this purpose, meaning 77\% efficiency (Bács And Bácsné 2014B). When examining subsidized areas of five visual team sports in general in Debrecen in 20112013 is can be stated that the least is spent on personal expences and then on infrastructural investments, the amount of which was even exceeded by the sum spent on replenishment training tasks. University students can take part in the competition (organised by TAO) as a result of which several universities have developed their sport infrastructure by means of tenders (Bács and Bácsné 2014A; Pfau 2015A,B).

The importance of replenishment training is crucial, seen from the Hungarian data of 2006 issued by National Sports Strategy Sport XXI. (2007-2020) showing that there were 200000 sports people having competition permit in our country, of which 138000 people were from the six popular visual team sport categories (football, handball, basketball, ice hockey, volleyball and waterpolo). The five visual team sports were completed by volleyball from this year (2017). Team sport (especially football, basketball, handball) play a very important role in the Universites 
sport (Bács and Bácsné 2014a, Bácsné 2014, Bácsné 2015; Pfau 2014a,b; PFAU and Domokos 2016).

Thanks to TAO, in every visual team sport increased the number of sports people (Ráthonyi-Odor and Borbély 2017). In handball sport TAO had inspiring effect on the growth of sports people's number, since in 2011.there were 24000 persons, in 2012. There were 25000 persons, in 2013. There were 29788 persons and in 2014. There were 31227 registered sportsmen (Bardóczy 2014; András 2014).

A research concerning basketball (Váczi 2017), based on a questionnaire filled in by 53 clubs from the 125 basketball teams working in Hungary (playing in National 1/A, National 1/B, National 2), speaks about the usefulness of TAO. The clubs revealed how much they were helped in different areas by the TAO. The clubs had to evaluate the areas on a scale from 1- to 5. ( $1=$ not at all helped, $5=$ totally helped). The clubs were mostly helped by TAO in implementation of investments (average $=4,38$, deviation $=1,14$ ), then in replenishment training (average $=4,42$, dev. $=0,79$ ), and in HR development (average $=4,11$, dev=0,78).

It is not only TAO which plays crucial role in replenishment training in Hungary. A good example on it is „Handball at School" programme managed by Hungarian Handball Federation.

In the Hungarian society value preference changed after the changes of the regimes, this way new expectations were expressed by the society about education as well concerning skills (Hamar 2005). This way curricula were continuously altered in education, four National Curriculums were issued. The latest alteration was in 2012 when the government accepted and ordered in Act (110/2012. (VI. 4.) the introduction of everyday physical education (Hamar 2013). This way everyday physical education was introduced in phasing out system from 2012, that is in the first year it was compulsory for the 1st and 5th year children of the primary school and for 9th year students of secondary schools, then it became compulsory gradually for the other classes as well. For everyday physical education "Handball at School" programme was created, a methodological material for training handball in junior classes (1-4 classes). This way schools could opt for two handball lessons out of the five physical education lessons a week. Hungarian Handball Association ensured the necessary equipment and training of the teachers. A curriculum was made for this handball programme which was published in Magyar Közlöny 2016. year 126. issue 5. attachment 22/2016. (VIII.25) EMMI order.

"Handball at School" programme was introduced in 2013 and schools continuously joined it: in 2013 year 1430 students took part in the programme from 50 schools, then in 2014 already 3400 children took part in it from 91 schools, by 2015 the number of children rose to 4565 from 117 schools.

Within the programme the children got acquainted with the basics of sponge handball in two lessons a week where they acquired the basic sport skills besides the elements of dribbling, possession and passing. The teachers training the children were trained, prepared and continuously controlled by Hungarian Handball Association.

Several Hungarian and international researches have dealt with the testing and choice of adult handballers (Granadoset al. 2007; Nikolaidis and Ingebrigtsen 2013; Serrien et al. 2016,
Schweising et al. 2016; Gürhan et al. 2016; Sabido et al. 2016, Schwesig et al. 2016; König and Ökrös 2016; König et al. 2017), and the importance of ICT in education (Czeglédi 2007, 2008; Nagy and Müller 2016 a,b; Nagy et al. 2017). Researches dealing with the measurement of children playing handball at school age also have literature background (Ingebrigtsen and Jefferys 2012; Diana et al. 2016; Karadenizli 2016; Muratovic et al. 2015; Kayapinar et al. 2015; Ingebrigtsen et al. 2013). Role of conditional abilities, mental stamina and performance indicators of adult elite sportsmen has also been examined by several professionals (Rivilla et. al. 2011, Csukonyi et al. 2015; Gürhan et al. 2016; Ökrös, 2016). The handball research done with children has proven that the sport has beneficial influence on the development of motorous skills of children (Ion 2015).

Before starting our research the following questions were asked we tried to find the answer for during our research. Which are the tests and procedures to examine the major conditional and coordinating skills, which are suitable to help the selection process of junior section pupils in handball sport? How will „Handball at School" programme affect in connection with general and sports-specific coordinational skills? How will target accuracy and speed coordination of pupils taking part in the survey change due to the project during the year? Which parameters will mostly have changed by the autumn and spring check? We consider that tests to check and examine conditional and coordinational skills, sports-specific tests must be approached in holistic way when finding talents for a sport in junior school age. We presume that there will be bigger development at children doing specific trainings in handball when doing ball coordination and speed coordination tests.

\section{MATERIAL AND METHOD}

The pupils were chosen, that in 2015-16 academic year at least $10 \%$ of all the students of the junior section take part in the programme. Out of 1430 pupils of the junior section 183 took part in the survey, that is $12,8 \%$ of it. The locations were chosen so that from Western- and Eastern Hungary and a school from the capital city be in the sample, so all the regions of Hungary were represented. It can be seen that there were about the same proportion of children from all the three locations (Figure 1.).

Figure 1. Sample by location

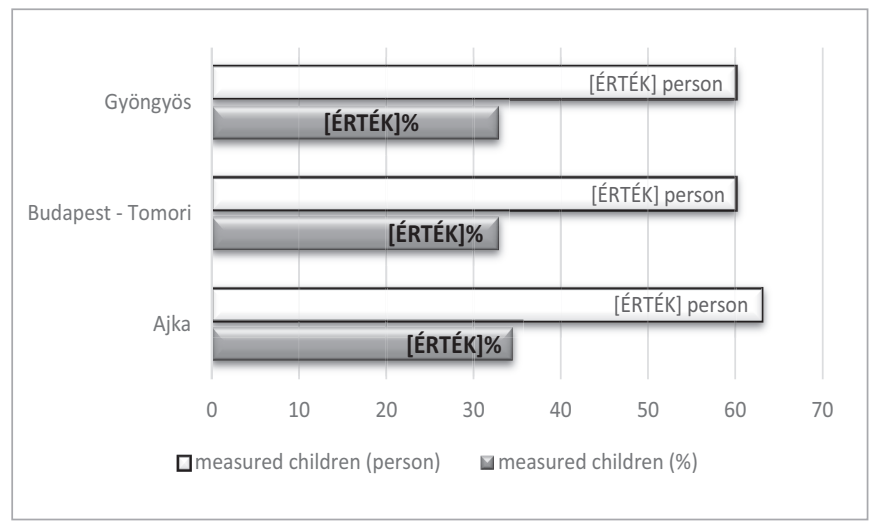

Source: Private edit 2017

94 persons $(51.4 \%)$ of the measured junior section children were boys, while 89 persons $(48.6 \%)$ were girls.The surveyed 
ones came from 2., 3. and 4. classes, with about the same proportion: 63 persons (34.4\%) 2. class, 57 persons (31.1\%) 3. class, and 63 persons (34.4\%) 4. class children. The Figure 2. shows the sporting habits of the sample:

Figure 2. Sporting habits of the sample

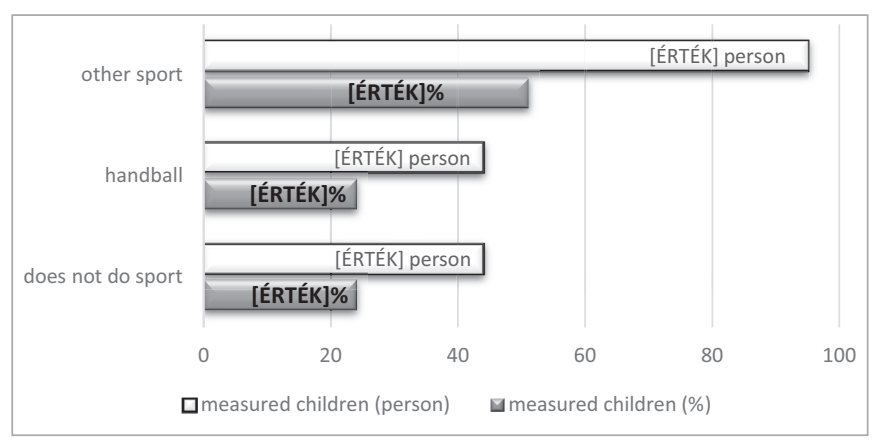

Source: Private edit 2017

Our experience concerning sporting frequency was that $24 \%$, that is 44 children of the sample do not do any sport besides physical education lessons, while $76 \%$ of the do some kind of sports activity. In the test group $24 \%$ of junior class children mentioned handball as sports activity, while $51 \%$ declared to do other sport.

The children were grouped by the age and the age groups were made by decimal age calculation. Our finding showed that $34,4 \%$ of the children in the sample were in the age group of 10 years old, representing the dominant part of the sample. $30,6 \%$ of the children were in the 9 year old category, while the 8 years old made $25,7 \%$ of the sample and the 11years old merely $4,4 \%$ of it and the 6-7 years old 5\% of the sample.

To test the survey material pilot measurements were done in Ózd, Vasvári Street Primary School, to make sure the test material offered for the survey matched the abilities of the age group and to get information about the feasibility of the exercises and general and special technical level - related to the tasks - of the students of different age and pre-training. This school was chosen to have a location where underprivileged children could also be tested and the venue is suitable to play sponge handball.

During the pilot research alterations were made in the previously suggested material, since the 1 . and 2 . class pupils could not perforn the 2. task (Alternate hand dribble with ball) even at basic level in alternative way. Therefore the above mentioned age group had to perform this task only with one hand (on the dominant side) during the survey. (Evaluation of this task will be published in a future article.)

Besides this - as the pilot test was done at the beginning of the school year -, the 1. year pupils could not be surveyed, since even understanding the task caused serious problems for them, as, lacking pre-training, they had never faced such kind of movement material.

The Surveyed Features and Positions
Movement accuracy is a very complex category in handball, therefore we tried to examine it through different factors in order to be able to give a complex summary on them later.

In our present article the results of our two surveys to test aiming accuracy are described. Therefore the description of these tests and their evaluation is also shown in details.

\section{Shooting in transversal straddle position without running up (to survey sports specific coordination skills)}

The aim of this trial was to measure sports specific coordination skills of the children, which means aiming accuracy and target accuracy in handball sport.

This trial is implemented by the children in the way that they stood behind the line drawn on the floor, then they had to hit the small box five times in standing position without previous swing. After the first implementation they were given some time to relax and the the shots were repeated five times again. The distance of the small box that is of the target surface was changed according to the age: the taget surface for 1-2 classes was 5.5 meters, while for 3-4 classes it was 6 meters from the line. The size of the target surface, small box: $26 \mathrm{~cm}$ height, $62 \mathrm{~cm}$ length, $42 \mathrm{~cm}$ width. When hearing the whistle of the teacher the student had to throw a ball taken from the nearby small box and hit the target surface so that the ball hit it with direct contact. Precise technical implementation was required, that is with upper throw.

\section{Shooting in transversal straddle position with running up}

At this task sports specific coordination of children was measured, with target shooting from movement typical of handball.

This trial, similarly to the previous one, had to be performed by standing behind the line drawn on the floor, they ran back from a line to the small box place 2 meters from the line, took a sponge ball from it, ran back to the line and had to hit the small box five time with the better hand, with proper technical implementation, the after some rest they did five new trials again. The distance of the small box that is of the target surface was changed according to the age, placed at the distances mentioned above.

The data gained during the survey were processed with the help of SPSS statistical software, basic statistical measures were calculated, like: average, deviation, median, modus. To measure correlations two-sample trial was applied. The results were drawn in graphic and table system.

\section{RESULTS AND DISCUSSION}

Implementation of shooting in transversal straddle position without running up, from stabil position is a task which can be expected from and can be performed by school children of junior age, since it is practised not only when being taught with sponge handball, but small-ball throw and throw are part of the natural exercises of athletics in the curriculum, 
it appears in school physical education games (dodgeball) or even in competitive- and relay races. The size of sponge handball used at the survey was the one used by the age groups, since the size of the palm is also different at the different age groups. This way grip stability implemented with a suitable sponge handball was adequate to the certain age groups.

However, it is well-known that there is a significant difference between the throwing technics, coordination abilities, muscular power of arms, etc. of the first- and fourth-year pupils. Therefore the tasks had to be differentiated, so different shooting distances were chosen, that is the distance between the target and the shooting place was different accordingly to the different age groups, which had been resultful in our previous surveys (pilot research). Since if the different age groups have to throw from the same dictance, the younger ones find it too difficult, while the older ones complete it almost without mistakes. The task accordingly with the age was determined in the way that the distance of the vertical surface of the small box for 2nd year pupils was 5.5 meters, while for 3-4th year pupils it was 6 meters. Differentiation of the shooting distance was necessary because not only throwing technics get better with age, but throwing performance as well, while aiming accuracy shows improving tendency, presumably thanks to taking part in the handball programme, and also the above mentioned distances are signed just like goal line for the different age groups. The students had two attempts. At each attempt they performed five shots so after some rest they had another five shots as second attempt.

In case of students the average score from the first 5 throws was 1,35 (deviation=1,17) in the autumn survey.

Table 1. The results of shooting in transversal straddle position without running up related to aiming accuracy, target accuracy, time results and technical implementation

\begin{tabular}{|l|c|c|c|c|l|}
\hline & \multicolumn{2}{|c|}{ Autumn result } & \multicolumn{2}{c|}{ Spring result } & \multicolumn{1}{|c|}{$\begin{array}{l}\text { paired t } \\
\text { test (p) }\end{array}$} \\
\cline { 2 - 6 } & average & deviation & average & deviation & \\
\cline { 2 - 6 } $\begin{array}{l}\text { First attempt Score } \\
\text { (pieces) }\end{array}$ & 1,35 & 1,17 & 1,94 & 1,28 & $\mathrm{p}<0,05$ \\
\hline $\begin{array}{l}\text { Second attempt } \\
\text { Score (pieces) }\end{array}$ & 1,42 & 1,15 & 1,95 & 1,22 & $\mathrm{p}<0,05$ \\
\hline $\begin{array}{l}\text { First attempt Lifted } \\
\text { elbow (pieces) }\end{array}$ & 3,29 & 1,92 & 3,8 & 1,56 & $\mathrm{p}<0,05$ \\
\hline $\begin{array}{l}\text { Second attempt } \\
\text { Lifted elbow } \\
\text { (pieces) }\end{array}$ & 3,29 & 1,84 & 3,84 & 1,53 & $\mathrm{p}<0,05$ \\
\hline $\begin{array}{l}\text { First attempt } \\
\text { Time(sec }\end{array}$ & 11,57 & 2,23 & 10,78 & 1,97 & $\mathrm{p}<0,05$ \\
\hline $\begin{array}{l}\text { Second attempt } \\
\text { Time(sec) }\end{array}$ & 11,13 & 2,13 & 10,29 & 1,98 & $\mathrm{p}<0,05$ \\
\hline
\end{tabular}

Source: Private edit 2017
After the first five shots they had some rest and then threw five times again, where the average value was 1,42 (deviation=1,15). The results of the second attempt, second aiming steadily showed better values. Müller (2004) had 10 relay kicks done by primary- and secondary school students to test aiming accuracy. It is proven that the fourth kick attempt was the best, because of the above mentioned ones. The tenth attempt proved the weakest result, as tiredness caused unfavourable tendencies in soft coordination (Table 1.)

In our research more precise aiming is shown by the fact that the deviation value measured at the second time is smaller, that is variation range of the output decreased showing more balanced aiming performance.

At the spring survey even efficiency of sponge-handball practices can be seen. During the spring survey the students performed this shooting task at 1,94 (deviation $=1,28$ ) value on average at the first attempt showing better shooting accuracy after the first semester than in autumn. The shooting results of the two measurements show significant differences. During the second row of throwing attempts students produced better values again, since the average of of scores improved from 1,42 to 1,95 on average and deviation increased from 1,15 to 1,22 from autumn to spring. The cause of it may be that progression to output may increase variation range of scoring performance. When checking the second series significant improvement was experienced at students $(\mathrm{p}<0,05)$, that is spring results are better than the autumn ones (Table 1.).

Besides scoring accuracy technical implementation, movement accuracy was also checked, the surveyor also watched at the certain throws how many times the attempt was performed with lifted elbow. The students performed the throw with lifted elbow 3.29 times, with 1.92 deviation value, out of 5 attempts at the first autumn series. At the spring measurement the task was performed with right techics 3.8 times on average, and with lower deviation value $(1,56)$. The more precise technical performance also improved efficiency, target accuracy. Compared to autumn results the improvement in technical implementation was proven by not only the smaller deviation, but also significant differences were experienced after doing the two sample-T probe. "Handball at School" programme had good effects also on improving technics. In the second series of the autumn survey students performed the exercise with lifted elbow 3.29 times, with 1,84 deviation value. The spring results were improved to 3.84 on average (deviation=1.53), which can be considered a significant difference (Table 1.).

Time spent on implementation was also measured, since motion pressed by time is also a peculiarity of ball games, determining in open-skill sports. However, understanding sports-specific connection between fastness and accuracy is also important.

The students performed the first series in $11.57 \mathrm{sec}$ (deviation=2,23) in autumn, which value decreased to 10.78 sec (deviation=1,97) by spring. The average value of the second series in autumn was 11.13 (deviation=2,13), which 
Having by-passed the second cone he goes on with right hand again until the third cone has been by-passed. The way back is the same as above, keeping the opposite side dribbling rule concerning the cone. (In 1st and 2 nd classes the teacher may conduct it - if necessary - which hand to use when dribbling in the given position.) There are four attempts. After two attempts there is a long break (he has a rest while the other members of the class also perform the task) after which he has two more attempts. Evaluation: By a digital watch, the hundredth of a second punctuality.

Dribbling trial with direction change is a sports specific

Table 4. Time results of running trial with direction change (with using ball) in the autumn- and spring measurements

\begin{tabular}{|c|c|c|c|c|c|}
\hline \multirow{2}{*}{ First attempt } & \multicolumn{2}{|c|}{ Autumn result } & \multicolumn{2}{c|}{ Spring result } & \multirow{2}{*}{$\begin{array}{c}\text { paired } t \\
\text { test }(\mathrm{p})\end{array}$} \\
\cline { 2 - 5 } & 13.36 & 3.58 & 12.41 & 3.40 & $\mathrm{p}<0.05$ \\
\cline { 2 - 5 } average & deviation & average & deviation & $\mathrm{p}<0.05$ \\
\hline Second attempt & 13.11 & 3.26 & 12.37 & 3.02 & $\mathrm{p}<0.05$ \\
\hline Third attempt & 12.45 & 2.89 & 11.80 & 2.65 & $\mathrm{p}<0.05$ \\
\hline Fourth attempt & 12.65 & 2.97 & 11.95 & 3.19 & \multicolumn{2}{|c|}{} \\
\hline
\end{tabular}

Source: Private edit 2017

test where the students accomplish the track with a sponge ball. This trial also measures speed coordination, however, possession of the ball, measuring ball skills is also done in dynamic conditions.

In the autumn test we experienced that the first attempt was accomplished in 13.36 seconds in general (dev.=3.58), while the second attempt in 13.11 seconds (dev.=3.26), the third attempt in 12.45 seconds (dev.=2.89), while the fourth attempt was accomplished in 12.65 seconds (dev.=2.97). It was experienced that the time results of the third and fourth trials were better compared to the first two ones. The experience of the first two accomplishments may have helped the better that is faster implementation, of the third and fourth trials, "they got to the task" (Table 4.).

When looking at the spring time results in the dribbling task, similarities can be experienced to the autumn measurements, (first attempt average $=12.41 \mathrm{sec}(\mathrm{dev} .=3.40)$, second attempt average $=12.37(\mathrm{dev} .=3.02)$, third attempt average $=11.80(\mathrm{dev} .=2.65)$, fourth attempt average $=11.95$ (dev.=3.19), that is the time results of the 3rd and 4th attempts were better compared to the first two ones. Proper warm-up is indispensable for speed tasks, which also may have resulted in the better results (Table 4.).

In case the autumn- and spring results are compared, improvement can be stated in all the four attempts, since the tasks were implemented faster, which not only show a tendency, but it could be proves statistically as well, as results of paired test showed significant differences.
In our pilot research and survey we experienced that in junior school age tests measuring and checking conditional a coordinational abilities, sports specific tests of handball must be applied in holistic approach when wording talent and choosing a sport. Our research has proven that in case of certain parametres (technical implementation, accuracy, shooting accuracy) „Handball at School” programme has positive effect on pupils performance.

„Handball at School” programme - meaning two sports specific lessons a week - has improved shooting accuracy results, technical implementation and speed coordination of all pupils alike. The programme improved speed coordination as well manifested in improving time results of trials with- and without ball proven statistically as well.

In our former measurements (Juhász et al. 2016; Juhász et al. 2017) we could also prove favourable impact of the programme on students of different age, gender and preeducation.The handball can play a very important role as a tools in the every-day physical education, because the program developed the motor skills for the pupils.

\section{ACKNOWLEDGEMENTS}

The publication is supported by the EFOP-3.6.2-16-201700003 project. The project is co-financed by the European Union under the European Social Fund.

\section{REFERENCES}

Aasrud A., Baron R. and Karousakis K. (2010). Market readiAndrás, K. (2014). A TAO támogatási rendszer sportgazdasági hozadéka. In: Petridis Leonidas (Ed.) A felsőoktatás szerepe a sportban, élsportban és az olimpiai mozgalomban, különös tekintettel a társasági adóból (TAO) támogatott sportágak helyzetére és a támogatások hasznosítására. c. konferencia Tanulmánykötete. Debrecen. 12-22.

Bácsné Bába É. (2015): Sportszervezetek működési kereteinek változása. Közép-Európai Közlemények. (No. 28) VIII. évf.:(1.) pp. 151-161. (2015)

Bácsné Bába É. (2014): Hallgatók, buli, Campus - Felsőoktatási hallgatók fesztivállátogatási szokásainak változása a Campus Fesztivál vizsgálata alapján. Turizmus Bulletin XIV.:(2.) pp. 33.42.. (2014)

Bács Z., Bácsné Bába É. (2014a): Sportkoncepció és szervezeti megvalósítása a Debreceni Egyetemen. In: Bartusné Szmodis Márta (szerk.) Sporttudomány az egészség és teljesítmény szolgálatában: XI. Országos Sporttudományi Kongresszus. Magyar Sporttudományi Szemle15. évfolyam 58. Budapest: Magyar Sporttudományi Társaság, p. 18.

Bács, Z., Bácsné Bába, É. (2014b). A TAO támogatási rendszer hatása és szervezeti kezelése Debrecenben. In: Leonidasz P. (Ed.), A felsőoktatás szerepe a sportban, élsportban és az olimpiai mozgalomban, különös tekintettel a társasági adóból (TAO) támogatott sportágak helyzetére és a támogatások hasznosítására: tanulmánykötet. Debreceni Egyetem Gazdálkodástudományi és Vidékfejlesztési Kar, Debrecen. 22-36.

Bakonyi, F. (1969). A testnevelés mennyiségének és minőségének befolyása a sportolási igény alakítására. A testnevelés tanítása. Művelődésügyi minisztérium módszertani folyóirata 5(3): 75078. Bardóczy, G. (2014). A látvány-csapatsport támogatások helyzete, 
perspektívái. In: Petridis Leonidas (Ed.) A felsőoktatás szerepe a sportban, élsportban és az olimpiai mozgalomban, különös tekintettel a társasági adóból (TAO) támogatott sportágak helyzetére és a támogatások hasznosítására. c. konferencia Tanulmánykötete. Debrecen. 50-72.

Czeglédi, L. (2008). IKT eszközökkel támogatott tartalomszolgáltatás.

In: Pethő Attila, Herdon Miklós (Ed.) Informatika a felsőoktatásban 2008: Előadás-összefoglalók és teljes előadást tartalmazó CD-melléklet. 227 p. Konferencia helye, ideje: Debrecen, Magyarország, Debreceni Egyetem Informatikai Kar.

Czeglédi, L. (2007). IT kompetenciák az információs társadalomban: Haladunk vagy maradunk? In: Lehoczky László, Kalmár László (Ed.) 1. microCAD 2007, M szekció: 27. International Scientific Conference. 246 p. Konferencia helye, ideje: Miskolc, Magyarország, Miskolci Egyetem Innovációs és Technológia Transzfer Centrum, pp. 25-30. Alkalmazott informatika.

Csukonyi, Cs., Kovács, I., Kiss, B. (2015). A mentális állóképesség és a teljesítménymutatók kapcsolata a csapatsportot űzők céljaival: Kézilabdázók és kosárlabdázók sporttal kapcsolatos célkitűzéses vizsgálati eredményeinek bemutatása. In: Balázs, K. (Ed.) Alkalmazott pszichológiai tanulmányok a Szociál- és Munkapszichológiai Tanszék fennállásának 25. évfordulójára. 256 p. Debrecen: Debreceni Egyetemi Kiadó, 151-172.

Dajnoki, K., Becsky, A., Szabados, Gy. (2015). Sportszervezetek HR sajátosságai. Debreceni Campus Kft., Debrecen, 161.

Granados, C. Izquierdo, M., Ibanez, J., Bonnabau, H., Gorostiaga, E.M. (2007). Differences in physical fitness and throwing velocity among elite and amateur female handball players. In. J Sports Med. 28:860-867.

Gürhan. S., Malik. B., Kürşat H. (2016). Comparison of Aerobic, Anaerobic Power Features Basketball and Handball Team Players. Niğde University Journal of Physical Education and Sport Sciences, 10, (3), 379-385.

Hamar, P. (2005). Értékelés - osztályozás - testnevelés. Iskolai testnevelés és sport - elméleti módszertani és információs szaklap (26) pp. 17-20.

Hamar P (2013).Balléri szellemiség - testkultúrába ágyazva. Új pedagógiai szemle 63:(7-8) pp. 93-98.

Ingebrigtsen, J., Jefferys, I. (2012). The relationship between speed, strength and jumping abilities in elite junior handball players. Serb J Sports Sci., 6, 83-88.

Ingebrigtsen, J., Rodahl, S., Jefferys. I. (2013). Physical Characterstics and Abilities of Junior Elite Male and Female Handball Players. J Strength Cond Res. 27(6):1708-19.

Ion, M. (2015). Training Modeling Children Beginners in Practice Handball Game. Procedia - Social and Behavioral Sciences, 180, 1269 - 1275.

Juhász, I., Boda, E., Bíró, M., Müller, A., Macra-Oşorhean, M.D. (2016). Impact of teaching handball on the improvement of target accuracy of students in consideration for the impact assessment of the project "Handball at school". Studia Universitatis Babes-Bolyai Educatio Artis Gymnasticae 61:(4) 15-27.

Juhász, I., Müller, A., Boda, E., Biró, M. (2017). A "Kézilabda az iskolában" címú iskolai program ismertetése és hatásának vizsgálata a tanulók motorikus teljesítményeire. Magyar Edző: Módszertani És Továbbképző Folyóirat, 19, (2) 52-56.

Karadenizli, I. (2016). The Effects of Plyometric Education Trainings on Balance and Some Psychomotor Characteristics of School Handball Team. Universal Journal of Educational Research 4. (10), 2286 - 2293.

Kayapinar, C., Aydemir, R., Aydemir, H. (2015). The Effect of Training Program on Physical Characteristics and Social Development of Boys. Academic Journal of Interdisciplinary Studies
MCSER Publishing, Rome-Italy, [S.1.], v. 4, n. 1 S2, p. 139, may. URL: http://www.mcser.org/journal/index.php/ajis/article/ view/6346.

König Görögh, D., Ökrös, Cs., Gyömbér, N., Tóth-Hosnyánszki. A. (2017). Magyar élvonalbeli utánpótláskorú kézilabda játékosok személyiségvonásainak összehasonlító elemzése. Magyar Sporttudományi Szemle 18:2 (70) 56.

König Görögh, D., Ökrös, Cs. (2016). Élvonalbeli utánpótláskorú játékosok személyiségvonásainak összehasonlító elemzése egy új megközelítésben. Magyar Sporttudományi Szemle 17:4 (68) 71-72.

Müller, A. (2004). Mozgásvizsgálatok a mozgásegyenletesség és a teljesítmény-konstancia példáján. Disszertáció. Nevelés- és Sporttudományok. 2004. Semmelweis Egyetem Testnevelési és Sporttudományi Kar Doktori Iskolája, Bp. Retrieved from: http://phd. semmelweis.hu/mwp/phd_live/vedes/export/mulleranetta-d.pdf NAT 2012. Új Pedagógiai Szemle 1- (3), 30 -256.

Muratovic, A., Petkovic, I., Bojanovic, D., Vasiljevic, I., (2015). Comparative analysis of motor and specific motor abilities between handball players and nonathletes in the cadet age from Montenegro. Acta Kinesiologica. 1, 70-74.

Nagy, Zs., Müller, A., Biró, M., Boda, E., Boros-Balint J. (2017). Study of the Basketball and Volleyball Thematic Unit Based on the Student s' Performance. Studia Universitatis BabesBolyai Educatio Artis Gymnasticae. 621, 29-41.

Nagy, Zs., Müller, A. (2016a). The role of the pulse measurement int he student's differentiated education applied in P.E. In: Physical Activity, Health and Prevention: International Scientific Conference: Conference Textbook of Invited Lectures. 106 p. (Ed.) Elena Bendíková, P. Mičko Konferencia helye, ideje: Banská Bystrica, Szlovákia, 2016.06.17 Banská Bystrica:Matej Bel University, 5-14.

Nagy, Zs., Müller, A. (2016b). The quantification of derivation in the volleyball thematic unit. In: Trendek és eredmények a biológiai kutatás és oktatás terén. (Ed.) Nagy Melinda, Poracová Jana). Komárno: Selye János Egyetem Tanárképző Kara, 55-62.

Nikolaidis, P.T, Ingebrigtsen, J. (2013). Physical and Physiological Characteristics of Elite Male Handball Players from Teams with a Different Ranking. Journal of Human Kinetics. Sep 30; 38: $115-124$.

Ökrös, Cs. (2016). Új edzés- és mérô eszköz (FitLight) alkalmazása a kézilabda sportágban. In: 46. Mozgásbiológiai Konferencia: Program, előadás-kivonatok: A Tíz Éve Elhunyt Rigler Endre Emlékének Szentelt 46. Mozgásbiológiai Konferencia. 29-30.

Pfau, C. (2014a). Szabadidősport és sportinfrastruktúra összehasonlító elemzése a kutató egyetemeken. Taylor: Gazdálkodás- és Szervezéstudományi folyóirat: a Virtuális Intézet Közép-Európa Kutatására Közleményei1-2, Szeged: 413-423.

Pfau, C. (2014b). Egyetemisták szabadidősport szokásai a Debreceni Egyetem Agrártudományi Központjában. Agrártudományi Közlemények/Acta Agraria Debreceniensis 58: 155-163.

Pfau, C. (2015a). Examination of Leisure Sports Alternatives Provided By Higher Education Institution. Apstract-Applied Studies in Agribusiness and Commerce. 9(3):33-39.

Pfau, C. (2015b).Analysis of the leisure sport activities in University of Debrecen. Apstract - Applied Studies In Agribusiness And Commerce 9:(1-2) 75-81.

Pfau, C., Domonkos Sz. (2016). Szabadidősport a felsôoktatásban. Taylor: Gazdálkodás- és szervezéstudományi folyóirat: a virtuális intézet közép-európa kutatására közleményei 23:(2) 111-118.

Ráthonyi-Ódor, K., Borbély, A. (2017). Sport - Finanszírozá eredményesség. Testnevelés, Sport, Tudomány / Physical Educa- 
tion, Sport, Science 2(1-2) pp. 67-73.

Rivilla, J., Martínez, I., Grande, I., \& Sampedro, J. (2011).

Relation between general throwing tests with a medicine ball and specific tests to evaluate throwing velocity with and without opposition in handball. Journal of Human Sport \& Exercise, 6(2), 414-426. https://doi.org/10.4100/jhse.2011.62.22

Sabido, R., Hernández-Davó, J. L., Botella, J., \& Moya, M. (2016). Effects of 4-week training intervention with unknown loads on power output performance and throwing velocity in junior team handball players. PloS One, 11(6), 1-12. https://doi. org/10.1371/journal.pone.0157648

Serrien, B., Clijsen, R., Anders, S., Goossens, M., \& Baeyens, J. (2016). Intra-seasonal variability of ball speed and coordination of two team-handball throwing techniques in elite male adolescent players. International Journal of Computer Science in Sport, 15(1), 1-21. https://doi.org/10.1515/ijcss-2016-0001

Schwesig, R., Hermassi, S., Hoffmeyer, B., Irlenbusch, L., Fieseler, G., Noack, F., Delank, K.S., Gabbett, T.J., Chelly, M.S. (2016). Relationship between the handball-specific complex-test and intermittent field test performance in elite professional handball players. J Sports Med Phys Fitness. 2017 Jun 21.

Schwesig, R., Koke, A., Fischer, D., Fieseler, G., Jungermann, P., Delank, K-S., Hermassi, S., (2016). Validity and Reliability of the New Handball-Specific Complex Test. In: Journal of Strength \& Conditioning Research, 30, (2) 476-486.

SPORT XXI. NEMZETI SPORTSTRATÉGIA (2007-2020). URL: http://kobanyasc.hu/docs/07sportstrategia.pdf

Váczi, P. (2017). Marketing és menedzsment módszerek a kosárlabda sportágban az Észak- magyarországi és Észak- alföldi régiókban. Phd. dolgozat. Debreceni Egyetem Agrár- És Gazdálkodástudományok Centruma Kerpely Kálmán Doktori Iskola. 149 .

Zhunisbek, D., Kudasheva, L., Kefer, N. Akhmetkarim, M. (2016). Methodological Features Physical Preparation of Students Handball Players. International Journal of Environmental \& Science Education, 11, (18) 375-386.

A nemzeti alaptanterv szerepe a tartalmi szabályozásban. URL: http://www.om.hu/letolt/kozokt/nat2003/kr/02_bevezetojavveg.rtf 